\title{
The 2009 Late Blight Pandemic in the Eastern United States - Causes and Results
}

W. E. Fry

Cornell University, Ithaca, NY

M. T. McGrath

Cornell University, Ithaca, NY

A. Seaman

Geneva, NY

T. A. Zitter

Cornell University, Ithaca, NY

A. McLeod

University of Stellenbosch, Stellenbosch, South Africa

G. Danies

Cornell University, Ithaca, NY

I. M. Small

Cornell University, Ithaca, NY
K. Myers

Cornell University, Ithaca, NY

K. Everts

University of Maryland, Salisbury

A. J. Gevens

University of Wisconsin, Madison

B. K. Gugino

The Pennsylvania State University, University Park

S. B. Johnson

University of Maine Cooperative Extension,

Presque Isle

H. Judelson

University of California, Riverside

J. Ristaino

North Carolina State University, Raleigh
P. Roberts

University of Florida, Immokalee

G. Secor

North Dakota State University, Fargo

K. Seebold, Jr.

University of Kentucky, Lexington

K. Snover-Clift

Cornell University, Ithaca, NY

\section{A. Wyenandt}

Rutgers Agricultural Research and

Extension Center, Bridgeton, NJ

N. J. Grünwald

USDA-ARS, Horticultural Crops Research Unit

C. D. Smart

Cornell University, Geneva, NY

New York Times, 17 July 2009:

"A highly contagious fungus that destroys tomato plants has quickly spread to nearly every state in the Northeast and the midAtlantic, and the weather over the next week may determine whether the outbreak abates or whether tomato crops are ruined..." (41).

New York Times, 9 August 2009:

"You say tomato, I say agricultural disaster" (7).

Indeed, the tomato late blight pandemic of 2009 made late blight into a household term in much of the eastern United States. Many home gardeners and many organic producers lost most if not all of their tomato crop, and their experiences were reported in the mainstream press. Some CSAs (Community Supported Agriculture) could not provide tomatoes to their members. In response, many questions emerged: How did it happen? What was unusual about this event compared to previous late blight epidemics? What is the current situation in 2012 and what can be done? It's easiest to answer these questions, and to understand the recent epidemics of late blight, if one knows a bit of the history of the disease and the biology of the causal agent, Phytophthora infestans (Boxes 1 to 5).

History. Western science first became aware of late blight in the early 1840 s, when a new disease of potatoes was observed in the United States in 1842 (47). However, the most famous outbreak of the disease was in Europe-observed and reported in early summer 1845. The disease was reported in Ireland by the fall of 1845 , and because the Irish peasants were so dependent on potatoes for sustenance, the destruction of potatoes (in the field and in storage) led

Corresponding author: G. Danies, Cornell University, Ithaca, NY; E-mail: gd243@cornell.edu

http://dx.doi.org/10.1094/PDIS-08-12-0791-FE

(C) 2013 The American Phytopathological Society to massive famine $(11,49)$. Since 1845 , late blight has been regarded as the most destructive of all potato diseases. The pathogen, once thought to be a fungus, is now understood to be an oomycete, quite distinct from the true fungi (1). Oomycetes are characterized by diploid nuclei in coenocytic vegetative cells, absence of chitin in cell walls, production of biflagellate zoospores from sporangia, oogonia and antheridia as gametangia, with the fertilized oogonium developing into a long-lived oospore. In the case of $P$. infestans, the sporangia are produced on aerial sporangiophores (Fig. 1) and are readily dislodged. Epidemics of late blight on potatoes and tomatoes are enabled by the rapid asexual growth and reproduction of $P$. infestans.

\section{The Pandemic in 2009}

The late blight pandemic in the summer of 2009 was unusual. It started synchronously in middle to late June over much of the northeastern United States. The pathway was via infected tomato transplants (Fig. 2) shipped to garden centers in large retail stores throughout the Northeast. The fact that infected transplants were being sold in such stores from Pennsylvania to Maine became abundantly clear by late June 2009. Most employees in the garden centers did not recognize the symptoms of late blight, and most home gardeners also were unaware of the disease and did not recognize it, so they planted infected transplants into their gardens. The first warning to the plant pathology community in the Northeast was from Andy Wyenandt who, on 18 June 2009, reported late 
blight on transplants in the garden centers of large retail stores incentral and southern New Jersey. This report was shared widely with plant pathologists in the Northeast via a "late blight" email list-serve organized by Abby Seaman in the NYS IPM program. This report was followed shortly by a report from Meg McGrath, who reported late blight on commercial potatoes on Long Island (23 June). However, the seriousness of the situation was not fully appreciated until 24 to 26 June, when plant pathologists in New York and Maine found infected tomato transplants in many large retail stores. The note from Tom Zitter on 26 June (Fig. 3) described the situation in Ithaca, NY. Zitter and others reported that transplants in large retail stores supplied by the same single national supplier were infected, but transplants in local garden cen-

\section{Box 1. Asexual cycle.}

Sporangia are the structures that are aerially dispersed and enable rapid spread of the disease. If deposited on a surface and then exposed to free moisture, sporangia can germinate (Fig. 1) to release (typically 8 to 12) biflagellated zoospores (18). Release of zoospores can happen within 2 hours of exposure to free water at cool temperatures $\left(10\right.$ to $\left.15^{\circ} \mathrm{C}\right)$. After a brief period of motility, zoospores settle, retract flagella, and affix themselves as a walled "cyst" to a surface. A germ tube from the cyst can penetrate host cells. Sporangia can also germinate "directly" by forming a germ tube. Direct germination typically happens at warmer temperatures $\left(15\right.$ to $20^{\circ} \mathrm{C}$ ), but at these higher temperatures only some $(<30 \%)$ sporangia typically germinate (14). After penetration of leaf tissue, the first symptoms can be visible within 60 hours (depending on host susceptibility and environmental conditions). Sporulation typically is stimulated by high moisture (near $100 \%$ relative humidity, or free moisture) and after the appearance of macroscopic symptoms. For some particularly susceptible tomato cultivars, sporulation may be the first macroscopic symptom (45). Thus, the asexual cycle can be completed within 96 hours under conditions optimal for the pathogen (favorable temperature, moisture, and a very susceptible host).

\section{Box 2. Sexual cycle.}

Phytophthora infestans is heterothallic, requiring two mating types (A1 and A2) for sexual reproduction (18). Production of gametangia (antheridia, oogonia) is stimulated by the close proximity of the two mating types, but exchange of nuclear material obviously requires physical contact of the two thalli. The result of sexual reproduction is an oospore that can survive adverse conditions, and can survive in a dormant state for years $(17,38)$. For nearly 100 years after initiating the epidemic in Europe in the mid-nineteenth century, only the A1 mating type was known to science (26). Then in the mid-1950s, the A2 mating type was discovered in central Mexico (46), and it was subsequently demonstrated that sexual reproduction was a consistent component of the life history of $P$. infestans in central Mexico (30). At the time, this contrasted with every other known population of $P$. infestans. It was not until late in the twentieth century that the A2 mating type was detected outside of central Mexico (in Europe) (32). The European detections most certainly resulted from migrations from Mexico (43). It was not until the end of the twentieth century that sexual reproduction was confirmed in Europe $(2,48)$. While sexual reproduction is suspected to occur in other locations where both mating types coexist, such demonstrations have not yet occurred.

\section{Box 3. Survival.}

In locations where only one mating type is present, this organism functions essentially as an obligate parasite, that is, it does not survive for extended periods without its host. Detached sporangia can survive for weeks in soil, where the duration of survival is dependent on environmental conditions $(6,36)$. In the atmosphere, the survival time of sporangia is measured in minutes or hours. If exposed to sunlight, sporangia die very quickly ( $<60 \mathrm{~min}$ ), but under cloudy conditions, sporangia in the air can survive for several hours $(39,40)$. In infected tissue, survival of vegetative mycelium is dependent on survival of the host. A heavily infected leaflet can become completely necrotic and dry up within a few days of becoming symptomatic. Such leaflets typically drop off the plant and are blown away. We are aware of no reports of hyphae or sporangia surviving in such dry tissue. However, because a stem dries so much more slowly than a leaflet, the pathogen can survive longer in stems, presumably as long as the stem contains some living cells and moisture. In infected tubers, survival is measured in terms of months, probably for as long as the tuber survives. Survival in infected potato and tomato fruits also is measured in terms of weeks, particularly in green fruits (unpublished results).

In sexual populations, long-term survival in the absence of a host is possible via oospores. Oospores can survive dry conditions and cold temperatures (20), but moderately high temperatures $\left(>43^{\circ} \mathrm{C}\right)$ are lethal (19).

Tuber-bearing solanaceous plants provide an excellent system for survival of vegetative stages of $P$. infestans. In natural systems, tubers of solanaceous plants are dormant until the next season, and an infected tuber provides a haven for the pathogen until the return of environmental conditions that enable its growth. In agriculture, potato tubers in the temperate zones are often stored overwinter in temperaturecontrolled (4 to $\left.10^{\circ} \mathrm{C}\right)$ bins, which enables survival of the pathogen in an infected tuber. If infected tubers are discarded into the environment (i.e., cull pile), the pathogen can sporulate from surviving tubers, and sporangia can be dispersed to neighboring host plants. When infected tubers are planted the next season, the pathogen can resume active growth. Although the vast majority of planted infected seed tubers do not lead to an epidemic $(12,16,31,39,40)$, a tiny proportion can. Because of the high growth rate of this organism, even a tiny survival rate in infected seed tubers can lead to a devastating epidemic in the field.

Compared to the potato production system, the tomato production system is less conducive to survival of $P$. infestans on a year-to-year basis. As far as we know, the pathogen does not survive asexually from one season to the next on dried tomato seed. Survival in the tomato production system is probably via some "bridge" plant. The bridge is most likely any of several alternate hosts (see [18] for potential alternate hosts) or hosts in alternate locations (i.e., potato tubers in the neighboring area, or tomatoes, petunia, or calibrachoa in a greenhouse or in a garden $[8,9])$.

The pathogen populations in the United States on tomatoes and potatoes reflect the diverse survival mechanisms in the two different production systems. A single clonal lineage (US8) has dominated the $P$. infestans population on potatoes in the United States and Canada from 1994 to $2010(23,25)$. This lineage was particularly aggressive and also relatively resistant to the fungicide mefenoxam $(29,34)$. It is easy to understand that once this lineage dominated the pathogen population on potatoes it was maintained in the system via its survival in tubers and subsequent planting of infected tubers as potato seed. In contrast, in the tomato production system, there has been a sequential diversity of lineages. 
ters, which had obtained tomato transplants from local sources, were free of late blight. From 24 to 30 June, there were 49 reports of late blight to the list-serve and the Northeast Plant Disease Network. Of these, 37 described infected transplants being sold in big box stores. Extension staff everywhere were alerted, and in New York, late blight had been reported in almost all counties by midAugust (Fig. 4). In many cases, extension personnel informed store managers that the infected transplants were dangerous to home gardens (Fig. 5), organic farms, and conventional crops. In some

\section{Box 4. Dispersal.}

There are several mechanisms by which Phytophthora infestans can be dispersed. Short-distance dispersal is achieved by wind and rain-splash of sporangia during irrigation events or during rainy weather. Additionally, sporangia can be dislodged from sporulating lesions onto farm equipment, animals, and clothing, and can then be deposited in another location. Sporangia are readily dislodged into the air and therefore are also wind-dispersed. Depending on conditions, sporangia can survive from minutes to hours in the air $(39,40)$. Thus, it is possible for viable sporangia to be deposited meters, hundreds of meters, or even thousands of meters away from the site of production.

Dispersal over longer distances (across several states, or intercontinental) requires human activity. In agriculture, the most efficient method for transporting this pathogen has been via infected potato seed tubers. Potato growers are all too aware that seed potatoes may be infected with $P$. infestans strains common where the seed potatoes were produced. For example, seed tubers produced in northern states are shipped south for production-as far as from Maine to Florida. Thus, there are many examples of transcontinental movement, and even intercontinental movement, of $P$. infestans in infected potato tubers $(24,43)$. More recently, other infected plants have become suspect in long-distance dispersal. Infected tomato transplants shipped in trucks were involved in the 2009 pandemic in the eastern United States. Other host plants (petunia and calibrachoa) in the commercial floricultural distribution system (10) could also play a role in long-distance dispersal. Additionally, infected tomato fruit in the food distribution system could enable long-distance dispersal of $P$. infestans. Symptomless infected fruits harvested at a production location can be shipped hundreds and thousands of kilometers rapidly. Once symptoms appear on these fruit, they are likely to be discarded. If discarded into the environment (i.e., compost pile, open dumpster) during the growing season, the pathogen could sporulate and become the source of inoculum for neighboring host plants.

\section{Box 5. Population structure of Phytophthora infestans} in the United States.

Populations of the pathogen causing an epidemic in a field in the United States have been mainly clonal and monomorphic for as long as we've had tools to assess their structure (25). The US8 clonal lineage has dominated populations on potatoes since 1994 (25). On tomatoes, the populations have changed over time. In the 1990s, US7, US11, and US17 had been important on tomatoes (23). However, the dominant lineage varied with region and over time. Thus, US7 had become rare by the late 1990s, and US17 had become rare before 2010 (33). Other strains were detected on tomatoes in the east during the early twenty-first century (33), but there were no major pandemics, and interest in the population structure of $P$. infestans waned until the summer of 2009. cases, store managers were helpfully responsive. However, because the transplants were on consignment (i.e., the store did not own them), some store managers felt that they could not summarily destroy the plants and had to depend on the supplier to remove the transplants. From 23 June to 29 July, we know of 155 reports of late blight from throughout the Northeast (Fig. 6). Reports of late blight on infected transplants in stores ceased after mid-July.

Weather in much of the Northeast was relatively favorable to late blight development during June and July 2009. For example, in central New York there was a steady accumulation of "severity values" on the Blitecast forecast (Fig. 7). This weather enabled $P$. infestans in infected transplants planted into home gardens to sporulate, disperse to, and infect neighboring potatoes and tomatoes (Fig. 8). A pandemic was initiated, and it caught the attention of the general population and news media in the Northeast $(7,41)$. Most early reports of late blight in the field were from home gardens and organic farms, where fungicides typically are not used. Commercial potatoes were largely unaffected in early 2009, probably because commercial potato growers typically apply fungicides to prevent late blight.

Reactions and impacts. Prior to 2009 (and in most subsequent outbreaks), late blight occurred in production fields where fungicide applications were applied unevenly, and rows or edges were missed. Extension personnel were surprised in 2009 because this outbreak was entirely different. Suddenly the disease was widespread on tomatoes in home gardens and in retail outlets throughout the Northeast. Communicating with the home gardener audience was a challenge because this audience is diverse and widespread, and often served by personnel who do not also serve commercial growers. Extension personnel quickly strengthened linkages with extension home and garden agents to educate the public about the need to take prompt action to protect crops.

Many homeowners and organic growers lost crops when a fungicide was not applied soon enough, and because they lacked highly effective curative fungicide choices. (Commercial growers, who have more fungicide options, were more successful in delaying the epidemic and subsequent yield loss.) Some other growers mistakenly thought their crops in high tunnels were protected. Persons who understood the destructive potential of this disease panicked because they did not know how close they were to a source of inoculum. Many organic growers and home gardeners lacked experience with late blight and were unfamiliar with the appropriate fungicides. In some locations, rain occurred relentlessly during the start of the pandemic, and even knowledgeable persons panicked because they could not get out to apply a fungicide, or because rain removed the fungicide immediately after application. For many roadside fresh market growers in the Northeast, tomatoes may be the most important source of income. One grower seeking advice explained that losing the tomato crop would result in financial ruin. Many persons wondered how the situation could get so bad so quickly. There was widespread anger that the situation occurred and that sales of infected plants were not halted more quickly.

Dismay was felt by many plant pathologists and extension personnel who tried unsuccessfully to stop sales by explaining the seriousness of late blight to managers of stores selling symptomatic tomatoes. Most store clerks had no comprehension of a plant disease and could not understand the implications of selling a diseased tomato plant from the garden center of a big box store. When admonished to remove infected transplants, one store manager responded by putting them on sale! Extension professionals expended tremendous effort and time into educating gardeners about late blight. Numerous web postings and flyers were produced. Press releases captured the attention of the media and public, and extension professionals provided many interviews for the written and broadcast media.

Denial, surprise, panic, confusion, anger, and concern were among responses from the public. Tomatoes are a crop regarded passionately by many gardeners. Once they understood the implications of late blight, they were horrified to learn that they had planted infected transplants in their gardens. Unfortunately, many 
gardeners learned about the devastation of late blight by observing their tomato plants dying seemingly overnight (Fig. 9). There was mass confusion initially because most gardeners (even very experienced ones) had never seen late blight. Some wondered if there might be health issues from breathing pathogen spores while tearing out diseased plants. There was some anger over the news that diseased plants were sold. Stores in one town are known to have offered refunds. Later in the year, other issues arose. Consumers were alarmed to see fungicide residues on tomatoes at farmers markets, especially on organically produced fruit, and sought answers about what the residues were and the implications to their health. Gardeners who had healthy plants until harvest had many questions: Were there any health concerns about consuming symptomless portions of affected fruit? Could the fruit be canned? How should they dispose of diseased tissue? How should they treat the soil? Upon destroying infected plants, some gardeners abandoned the remainder of the garden; others burned the clothing they wore when destroying the infected plants. Some annual tomato festivals were canceled.

Some fungicides, notably those approved for organic production, were not always readily available. Agricultural chemical manufacturers and distributors had not previously experienced such a pandemic and were as surprised as everyone else. However, federal and state agencies responsible for pesticide registrations promptly responded to the low supply of some fungicides, and they approved at least one supplemental label. Some organic growers were unable to effectively manage late blight, partly because of pesticide use restrictions.

The pathogen in 2009. Because infected transplants in June 2009 were associated with a single supplier throughout the Northeast, it seemed important to determine if the isolates causing late blight in these large retail outlets were similar to or different from each other. Many samples of infected tissues were shipped to Cornell University's diagnostic labs during the summer. Sporangia of $P$. infestans from these samples were assayed for allozymes at the glucose-6-phosphate isomerase (Gpi) locus. This assay can be completed in just a few hours (28). All samples from large retail stores, from organic farms, and from home gardens had the same (Gpi) genotype (100/122). The most informative technique then used was DNA fingerprinting using fingerprint probe RG57 (27). However, this technique requires a significant amount of pathogen tissue (for DNA extraction), so we obtained pure cultures of $P$. infestans from many samples. We then also assayed pure cultures for mating type and mefenoxam sensitivity. As the results gradually came in over the summer, we learned that all of the isolates from large retail stores, home gardens, and organic farms were similar to each other: they were all A2 mating type, had the same DNA fingerprint (Fig. 10), had the same Gpi genotype (Fig. 11), and were sensitive to mefenoxam. Unfortunately, these additional data did not become available until the epidemic was well established. The pandemic strain was termed US22 (33) (Table 1).
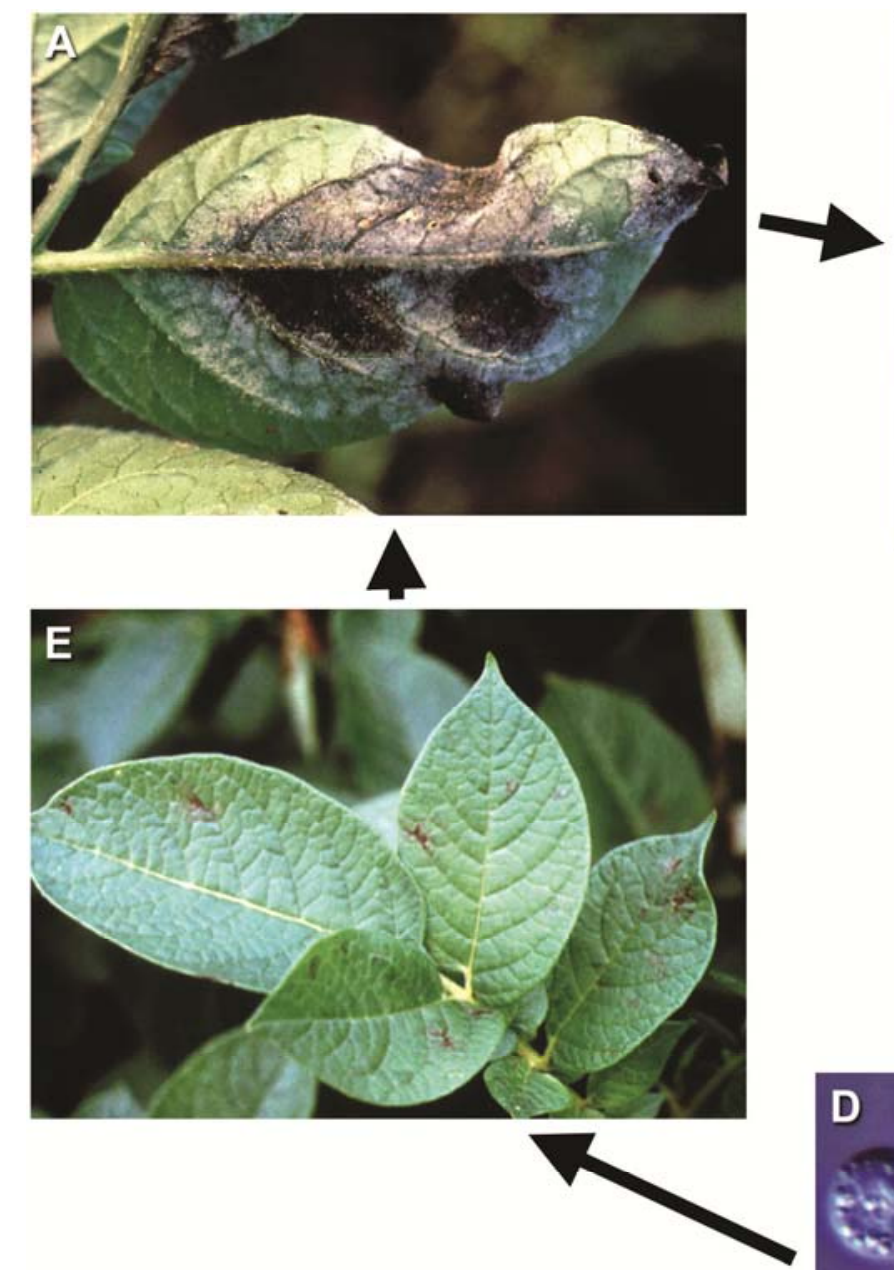
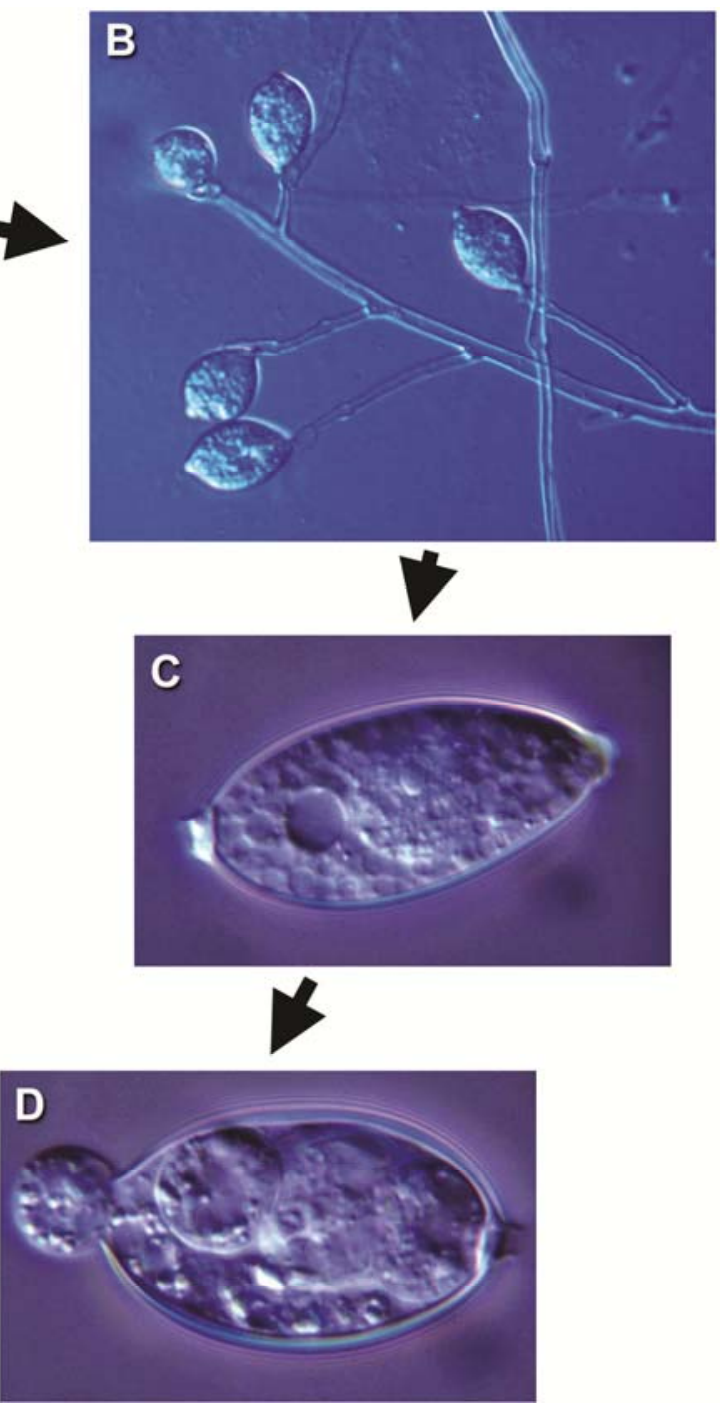

Fig. 1. Stages in the asexual cycle of Phytophthora infestans. A, Sporulation on a potato leaflet. B, Micrograph of sporangia on a sporangiophore. C, Detached sporangium. D, Sporangium from which a zoospore is being released. E, Young late blight lesions on potato leaflets. (This figure was first published in [21].) Images were obtained by W. E. Fry, R. V. James, and B. G. Turgeon. 
Rapid genotypic assay. When we learned in late July 2009 that the strain causing the pandemic was sensitive to mefenoxam, it became clear that a technique to rapidly identify this particular strain was highly desired. The allozyme assay was insufficient, because although it could be applied to sporangia from a sporulating lesion on the day of receipt in a lab, and results could be obtained in a few hours, the assay was insufficiently discriminatory. Other diverse strains could have the same allozyme genotype by chance. We therefore initiated an analysis of microsatellite markers to assess diversity among the strains, employing the procedure described by Lees et al. that determines genotypes at more than 10 loci (37). Microsatellite markers are polymerase chain reaction (PCR)-based and therefore can be employed on small samples (sporangia from lesions), and typically the results can be obtained

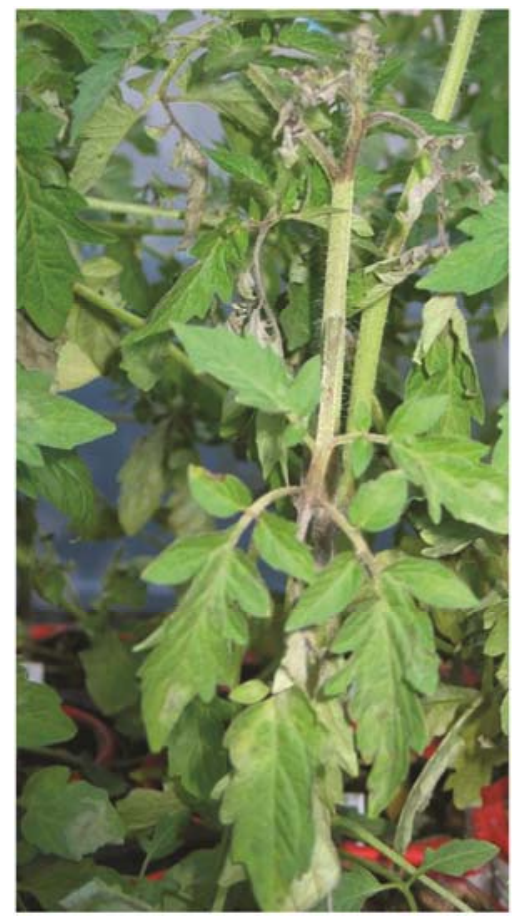

Fig. 2. Infected tomato transplant for sale in a large retail store in 2009. in $24 \mathrm{~h}$. Using the Lees et al. protocol, we were able to obtain a multilocus genotype that separated the 2009 pandemic strain from other recent strains (Fig. 12). Thus, microsatellites became a very useful tool to rapidly identify specific clonal lineages. If the phenotypic characteristics of a strain were already known, one could use microsatellites to rapidly predict the traits of the pathogen in any given sample.

Other strains. While US22 dominated the population in the Northeast in 2009, a few other clonal lineages were also detected. US8 (Table 1) was detected in a few samples from commercial potatoes. After the summer of 2009 and upon assessment of additional samples, it became clear that another lineage (US23) was present in the east (PA) and south. However, US23 did not appear to have been distributed on tomato transplants, and was not detected in the northeastern United States during the summer of 2009. Finally, another new strain (US24) was reported on potatoes from the upper midwestern United States. US8, US22, US23, and US24 can be distinguished from each other by their allozyme genotype (Table 1), RG57 fingerprint, and microsatellite genotype. The phenotypes of these lineages are also distinct from each other (see below).

\section{0}

Late blight in 2010. Late blight was not nearly as severe in the eastern United States in 2010 as it was in 2009. This is despite the fact that the weather in at least some locations was similarly favorable (Fig. 7). The big differences were that tomato transplants were free of late blight and that home gardeners and organic growers were particularly vigilant. Despite these changes, there were still some reports of late blight. The genotypes of $P$. infestans detected in 2010 were similar to those identified in 2009. US22 had been expected to be dominant, and indeed it was detected in many locations. However, in addition, US23 was detected more commonly, and US24 continued to be detected in the midwestern and western United States.

Phenotypes of common lineages. Isolates of four lineages (US22, US23, US24, and US8) collected in 2010 were investigated for phenotypic characteristics such as pathogenicity on potato and tomato (Fig. 13), sensitivity to mefenoxam, and speed of germination $(15,42)$. These isolates (total $n=59$ ) came from many different locations (in 12 states and one Canadian province). The number of isolates of each lineage ranged from 8 to 35 . These laboratory

Date: Fri, 26 Jun 2009 08:32:16 -0400

To: CCE-STAFF-LATEBLIGHT-L@ cornell.edu

From: Tom Zitter<taz1@cornell.edu>

Subject: Late Blight in Local Stores

$\mathrm{Hi}$ all,

Just a followup to my earlier report. Yesterday I did a quick tour of garden centers in the Ithaca area. All three big retail stores had late blight infected tomatoes on their shelves yesterday afternoon. Some agreed to remove the plants while I was there, and others were waiting word from the NY supplier. Tomato plants had been replaced with additional plants every few days. Plants appear to have originated from a producer in New York, and after speaking to them, they were in the process of remove plants from shelves. When I visited 4 local retail outlets, some close to the larger stores, I found no additional infected plants. These tomato plants had been grown by the local retailer or had been gotten from other NYS producers near Syracuse and elsewhere. I also received word that LB infected plants from large retailers were found in Sayre, PA, Schenectady County, and as far east as Presque Isle, Maine and beyond. NYS Ag and Mkt inspectors were to visit the NY producing site and take appropriate action.

Tom Zitter

Fig. 3. Message from Tom Zitter to the late blight list serve on 26 June 2009. 
assessments confirmed preliminary field observations. First, both US22 and US23 are pathogenic to both potato and tomato. However, it seems that US23 might be even more aggressive than US22 on both potatoes and tomatoes. This discovery supports the conclusion that a major reason for the pandemic of 2009 was that US22 was so widely and efficiently dispersed on tomato transplants, not that US22 is more aggressive than other strains. US22 and US23 are also fairly sensitive to mefenoxam. US24 is mainly pathogenic on potatoes, and not at all aggressive to tomato. These pathogenicity characteristics are similar to those of US8. Most individuals of US24 are sensitive to mefenoxam, but there may be some diversity in this lineage for mefenoxam sensitivity (see [15,42] for details). US8 has been previously characterized, and the 2010 isolates (Table 1) were shown to have characteristics similar to isolates collected in the 1990s. The phenotypic characterization has only just begun, and there may be other important differences among the lineages. For example, we have recently learned that US22 and US23 release zoospores more slowly than do US8 and US24 (15).

We were very interested in determining whether or not the expression of a particular trait within a lineage was consistent among isolates of that lineage. If it is consistent, then we will be able to make predictions of phenotype based on knowledge of genotype (lineage). For the 59 isolates in the four lineages investigated by Danies et al. (15), it appears that isolates within most lineages have fairly consistent phenotypes. However, some isolates in lineage US24 appeared to be sensitive to mefenoxam, based on an in vitro assay using mefenoxam-amended plates, whereas others were intermediate (42).

Research and extension response. The epidemic of 2009 reawakened interest in late blight. In 2010, this interest coincided with an opportunity from USDA AFRI (NIFA) to submit a researchextension proposal focused on oomycetes. Such a proposal (with $>25$ co-principle investigators, including participants from 13 states in the United States and two other countries) was constructed and submitted to the USDA. Fortunately, the proposal was funded and the project started in March 2011. This grant supports many efforts in extension and research (ranging from very basic to very applied). Because US22 appears to be thwarted by tomato resistance genes $P h 2$ and $P h 3$, tomato cultivars with these forms of resistance have been targeted for rapid development. Other approaches to developing host resistance are also being investigated. Other basic research has the practical goal of developing rapid diagnostic tools, such as a rapid diagnostic test for mefenoxam resistance. Participating extension plant pathologists are heavily involved, not only in education but also in rapid diagnosis and reporting. These plant pathologists have agreed to report occurrences of late blight to the USAblight website (http://usablight. org/) and to send samples for genotypic analyses. Because of the explosive potential of late blight, early warning is crucial to effective suppression.

\section{1}

Late blight in 2011. In 2011, the participants of the NIFA grant have agreed to keep each other and their stakeholder communities informed of events during the season. More than 150 samples in the eastern United States were submitted via overnight courier to our labs. These samples were assayed using microsatellite markers and allozyme analysis. Because fresh samples sent overnight often have sporulating lesions, it was possible to analyze many samples immediately upon receipt. For at least $80 \%$ of the samples submitted during the growing season, the clonal lineage in the sample was determined and the information returned to the submitter within 24 to 48 hours of receipt of the sample. Because the phenotypic characteristics of the common lineages were already known (Table 1), lineage identification could be used to provide more informed management decisions. After the growing season, additional samples collected in the midwestern and western United States were assessed. The total number of samples collected in 2011 was nearly 200.

Again there were a few very dominant lineages, and these varied by region. US22 was common in eastern United States and was detected first on tomatoes in June in southern Maine. However, it was not until August that US22 was again reported (on tomatoes in Maine and in New York). US22 was not the most commonly detected strain in 2011; instead it was US23 that was most commonly detected. US23 was found on tomatoes in a greenhouse in Connecticut in April, and there were many more detections each month through October. US23 accounted for about one-third of all samples from the eastern and midwestern United States in 2011. These samples came from Pennsylvania, Connecticut, Rhode Island, New York, New Hampshire, Maine, and Wisconsin. US23 was found predominantly on tomatoes, but also there were potato samples
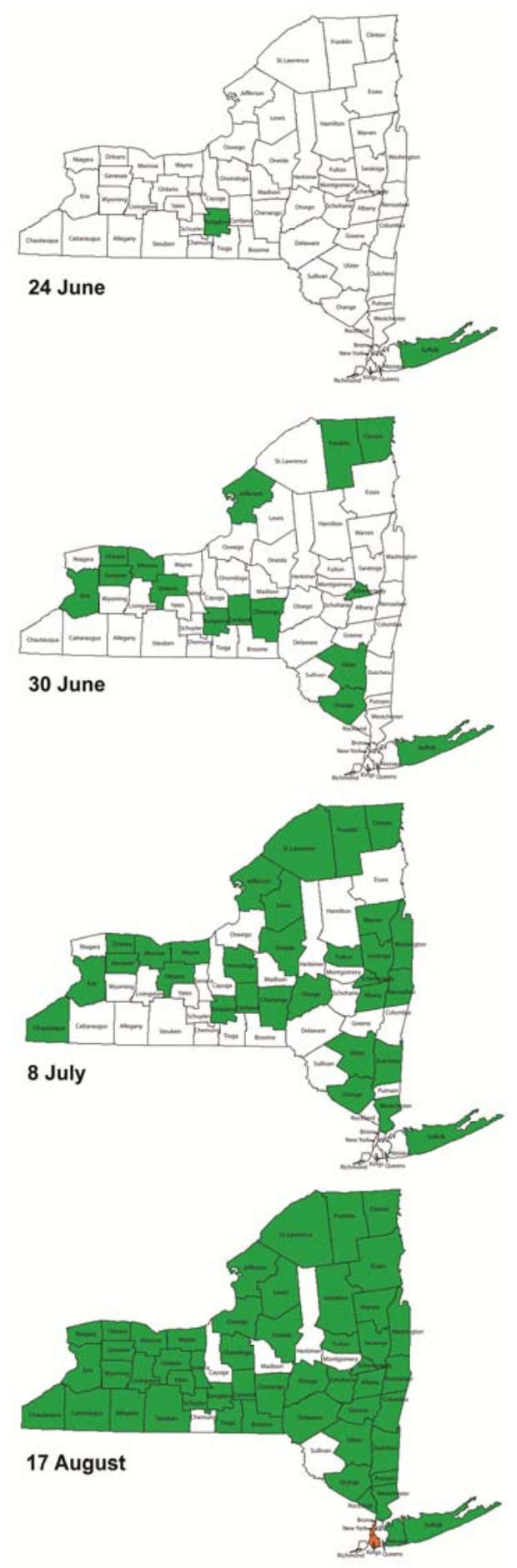

Fig. 4. Maps of New York State illustrating those counties that had reported cases of late blight (in a large retail store or in the field) on 24 June, 30 June, 8 July, and 17 August 2009. 


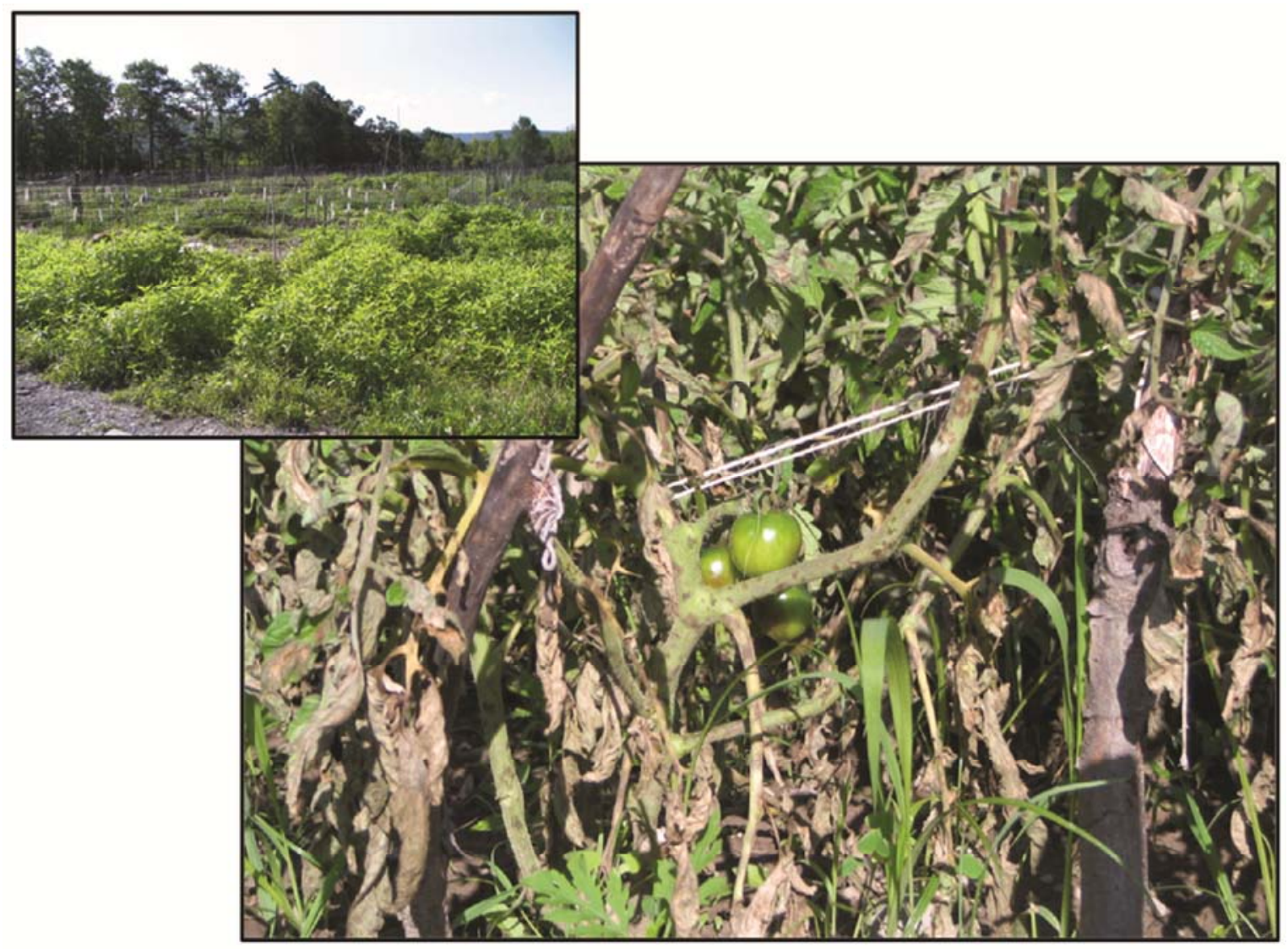

Fig. 5. Image of community gardens (inset) with a close-up of a late blight-infected tomato plant in one of the gardens. The images were taken on 9 July 2009.

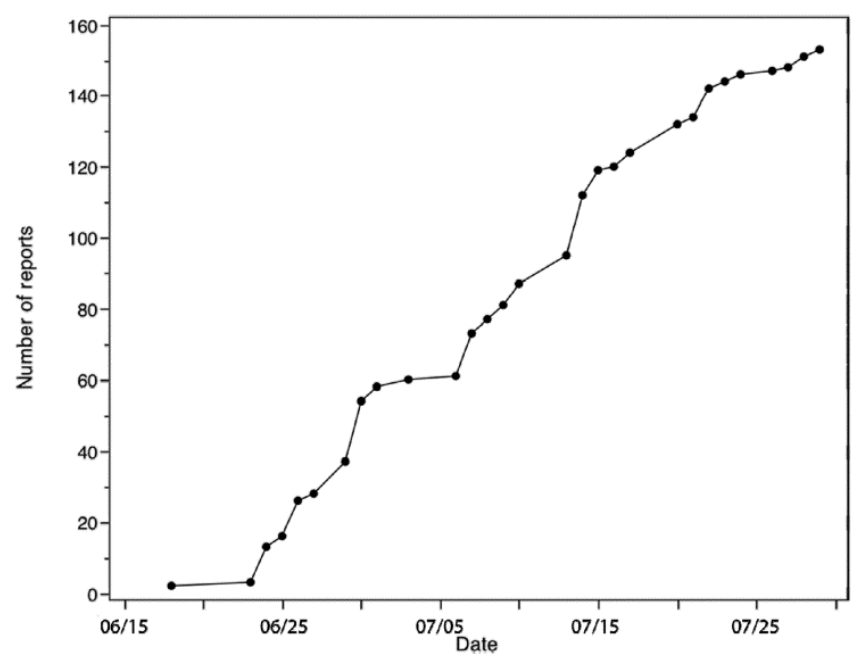

Fig. 6. Cumulative reports of late blight to the Cornell diagnostic lab from 18 June to 29 July 2009.

with US23. US24 was common on potatoes in the midwestern and western United States-being detected first on seed tubers prior to planting but also during the growing season. For the first time, there were also detections of US24 in the eastern United States: in Maine and New York. Interestingly, US11 was detected on tomatoes in California. US11 was prevalent in the mid-1990s, but had not been reported recently (33).

Additionally, several rare and new genotypes were detected in the east during the summer of 2011 (Fig. 12). Several of these diverse genotypes occurred in central New York, sometimes from the same farm. These isolates are currently being characterized and will be investigated to discern if they could represent a progeny of a sexual recombination event.

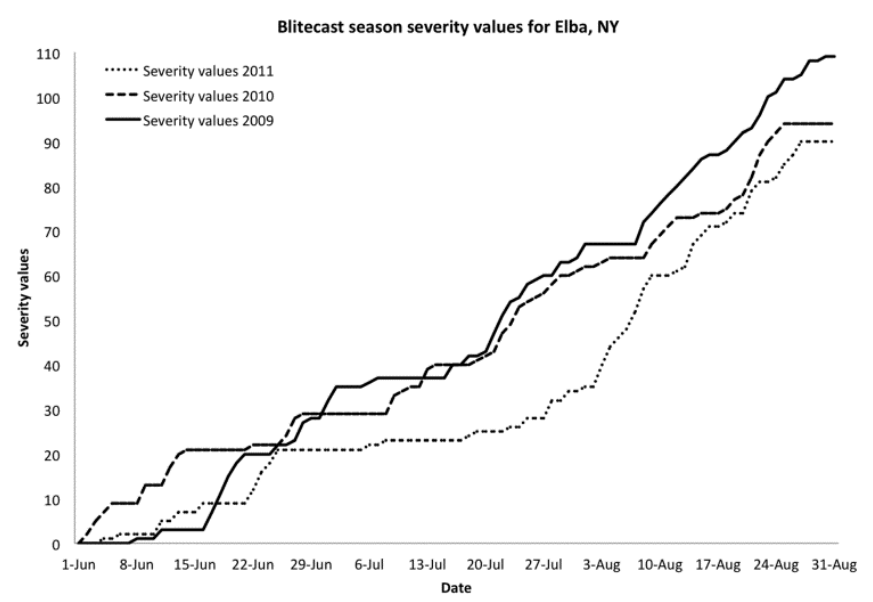

Fig. 7. Cumulative Blitecast severity values during 2009, 2010, and 2011 for Elba, NY. "Blitecast Severity Values" indicate how favorable the weather has been for late blight (35). There may be up to 4 severity values added in a single day.

Communications. Because of the potential speed and devastation of a late blight epidemic, rapid diagnoses and rapid communications are important for effective late blight management. For example, if US24 is detected in an area, potatoes are at greater risk than are tomatoes, but mefenoxam may have some efficacy. Similarly, if US23 is in the vicinity, both potatoes and tomatoes are at risk, but again, mefenoxam may be effective. On the other hand, if US11 is in the vicinity, both potatoes and tomatoes are at risk, and mefenoxam is unlikely to be effective. In several cases in 2011, rapid communication concerning the identity of the lineage causing the problem was useful to the grower in determining the most effective response. In addition, personnel in the eastern United States were alerted to late blight in their area via a website estab- 
lished by the NIFA project, which included maps of occurrences (http://www.usablight.org/map).

Decision Support System (DSS) for late blight management. Many of the participants in the AFRI grant have participated in the evaluation and improvement of a DSS that provides near "realtime" information for late blight management. This DSS is available via USABlight or directly at http://blight.eas.cornell.edu/ blight/. After the initial set-up, the DSS provides weather data from the nearest weather station (including on-farm weather stations), and also highly localized (4-km grid) weather forecasts. The weather data are updated several times per day. Both observed and forecast weather data are used in two late blight forecasts (Blitecast [35] and Simcast [22]) hosted on the DSS. The forecast weather can be used to provide information concerning the potential future need (up to 7 days into the future) for fungicide application. The weather data can also be used to drive a simulator of late blight (3$5,13)$ that is available on the DSS. Simcast enables a ready integration of weather, host resistance, and fungicide use data into a simple late blight forecast. Future improvements are to include lineage-specific traits into Simcast. Several alerts are available in the DSS. One is an alert from Blitecast to indicate when in the

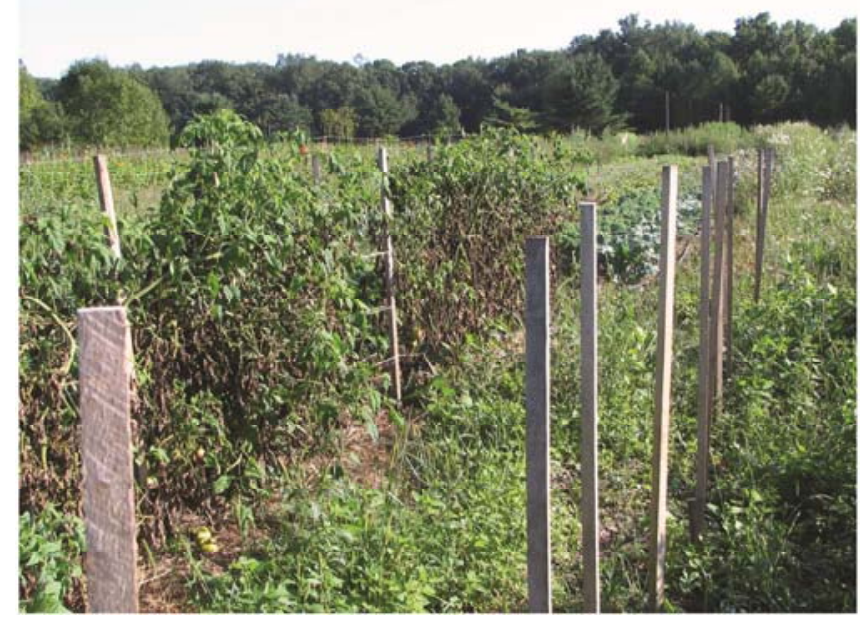

Fig. 8. Tomatoes with late blight on an organic farm near Ithaca, NY, in early August 2009. This row of tomatoes was the last remaining row and was destined to be destroyed. All other tomatoes had been removed because they were severely diseased.

Date: Fri, 24 Jul 2009 18:03:47 -0700 "FYI: I am an organic gardener in Amsterdam, NY with 63 heirloom tomato plants of 23 different varieties, all gone. I was growing very rare varieties, blacks, greens, oranges, whites. All purchased from a very reputable grower in Schoharie. Tonight I had to leave home as my husband is pulling and bagging all 63 plants. I have $100 \%$ loss. We live on ten acres. I inspected every day and it seems the blight took my plants in matter of hours. I was hoping to sell them for additional income."

Fig. 9. E-mail message from a distraught tomato grower whose tomato crop had been completely destroyed by late blight by late July 2009 . season the accumulated weather has been sufficiently favorable to trigger an initial fungicide application. Additionally, there is an alert ("inoculation alert") currently under development to notify the user if late blight has been reported within a radius of 50 kilometers and if the weather patterns have been such that the user's crop might be subject to inoculation and disease development.

\section{Explanations for 2009}

This review began by asking several questions. We return here to answer those questions.

1. "How did the 2009 pandemic happen?" The pandemic was initiated by a synchronous region-wide distribution and release of one strain of the pathogen into the environment on infected tomato transplants bought home by unsuspecting gardeners who were not aware of the symptoms and potential devastation of late blight. The subsequent weather in the region was favorable to the pathogen, and susceptible hosts were readily available, so that all requirements necessary for a pandemic were met.

2. "What was unusual about this epidemic?" In our experience, the scale of pathogen release was completely unexpected and unprecedented. The pathogen was released via infected tomato transplants throughout the entire Northeast at the same time. No one

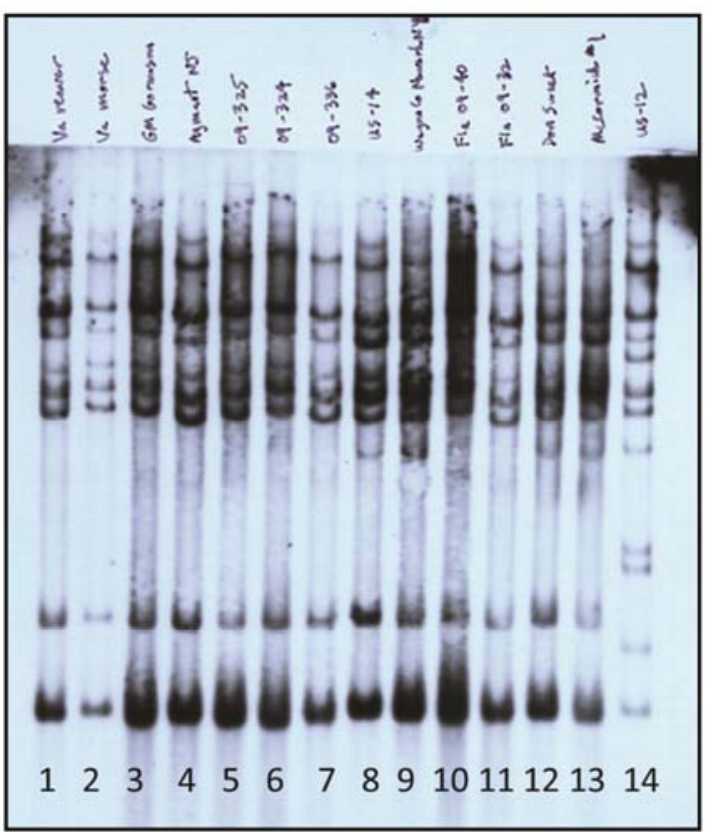

Fig. 10. Southern blot of DNA showing the DNA "fingerprint" of different individuals of Phytophthora infestans as revealed with probe RG57. Each column contains the DNA of a single isolate. The DNA had been cut with restriction enzyme EcoR1, and then fragments were separated on an agarose gel. The analysis was conducted in July 2009. Lanes 8 and 14 are controls. Lanes 9, 12, and 13 are US8. Lanes 1 to 7 and 10 to 11 are US22.

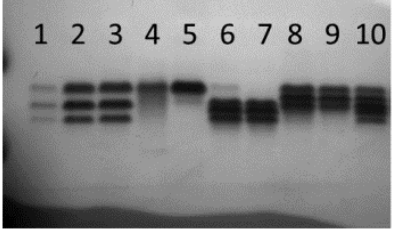

Fig. 11. Polymorphism at the glucose-6-phosphate isomerase locus using cellulose acetate. Each lane contains proteins from a single isolate of Phytophthora infestans. The proteins are separated via migration in an electric field, and then their locations are detected colorimetrically via an enzymatic reaction. Genotypes of the individuals in the diverse lanes are as follows: lanes 1 to 3 are 100/122 (US22); lanes 4 and 5 are 100/100; lanes 6 and 7 are 111/122; lanes 8 and 9 are 100/111; lane 10 is $100 / 111 / 122$ (US8). 
was prepared for this avenue of pathogen distribution on such a large scale. Obviously, if one aspect of the system is dominantly influenced by a single supplier, then any mistake may have significant consequences. Ignorance on the part of employees in the retail distribution system exacerbated the problem.

3. "What is the current situation and what can be done?" We have described the current situation, and we believe that new understanding, education, and communication have contributed greatly to the effective management of this disease in 2010 and 2011 compared to 2009. Future research needs to be multifaceted with the understanding that integrated strategies have the best chance for success.

Table 1. Characteristics of dominant clonal lineages of Phytophthora infestans recently detected in the United States

\begin{tabular}{lccccc}
\hline Lineage & Mating type & mtDNA $^{\text {a }}$ & Host specialization & Glucose-6-phosphate isomerase & Mefenoxam sensitivity \\
\hline US8 & A2 & Ia & Potato & $100 / 111 / 122$ & I-R \\
US11 & A1 & Ia & Potato/tomato & $100 / 111$ & R \\
US22 & A2 & Ia & Potato/tomato & $100 / 122$ & S \\
US23 & A1 & Ia & Potato/tomato & $100 / 100$ & S \\
US24 & A1 & Ia & Potato & $100 / 100 / 111$ & S (some I) \\
\hline
\end{tabular}

${ }^{a}$ mtDNA = mitochondrial haplotype. Four haplotypes have been found most commonly over the past several decades: Ia, Ib, IIa, and IIb.

b Most individuals of US24 appear sensitive (S) to mefenoxam, but others appear intermediate (I) in their sensitivity based on an in vitro assay using mefenoxam-amended plates. US11 has been consistently resistant (R). Data are from Myers et al. (42).

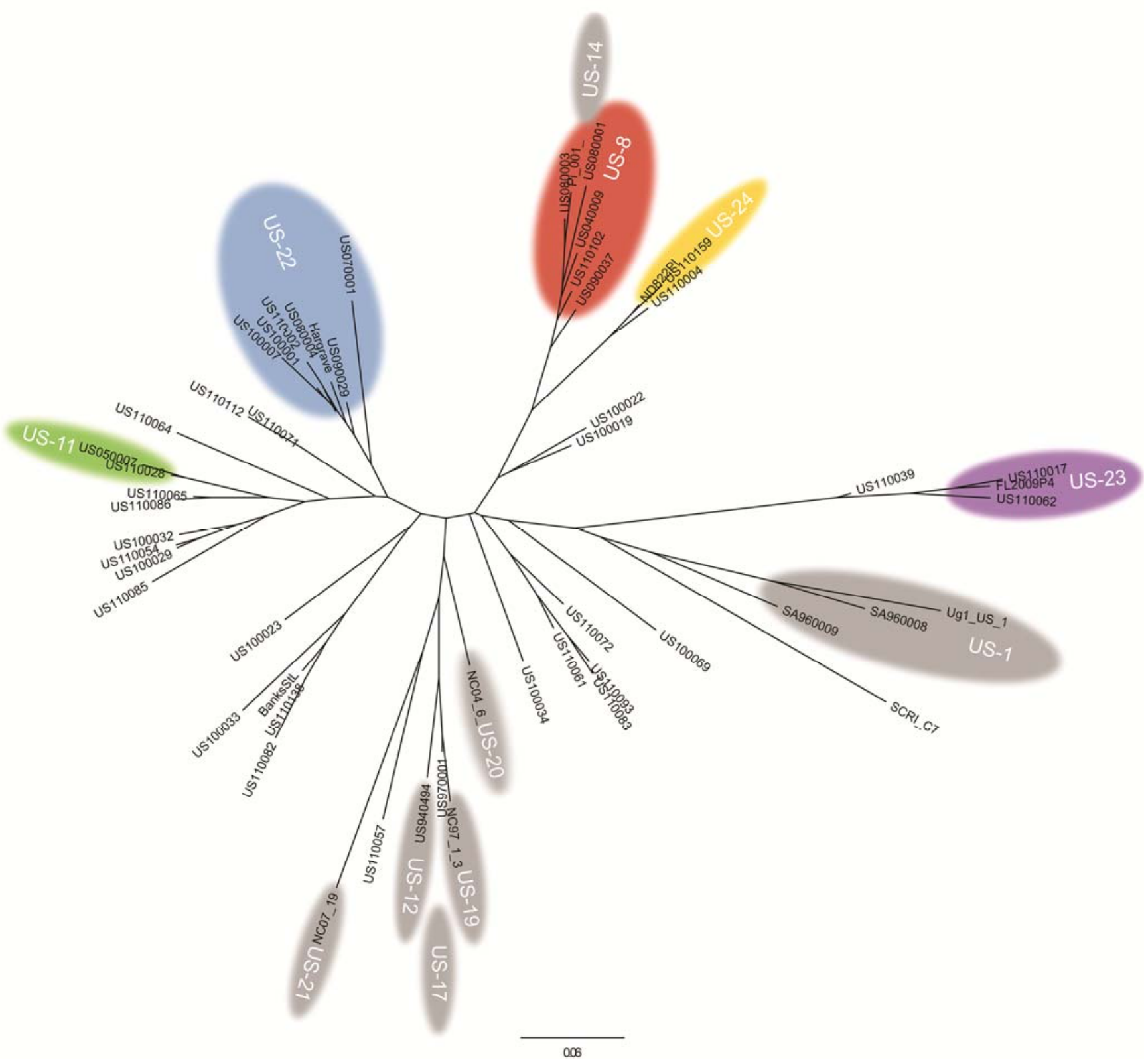

Fig. 12. Dendrogram illustrating the relationships among recent clonal lineages of Phytophthora infestans collected in the United States as revealed using microsatellite markers. Distances among genotypes were calculated using Bruvo's distance and visualized with an unrooted neighbor-joining tree by David E. L. Cooke (James Hutton Institute, Invergowrie Dundee UK DD2 5DA). Colored overlays represent multilocus genotypes based on GPI, RG57, and Mating type information (44). 


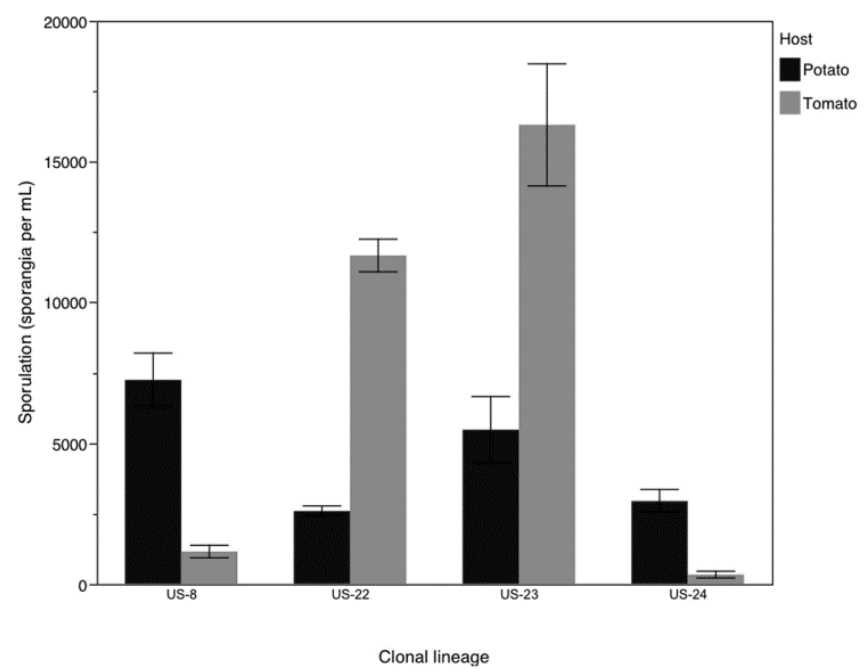

Fig. 13. Pathogenicity of different lineages of Phytophthora infestans on potato and tomato. The numbers of isolates involved in the assessments were US8 (8), US22 (35), US23 (7), and US24 (9). Data are from Danies et al. (15). The graph shows the mean $+/-$ standard error of sporulation counts.

\section{Next Steps}

Many new technologies and approaches are needed to realize more effective late blight suppression in the future. These include: improved communications, better weather forecasts, improved knowledge of aerial dispersal of $P$. infestans, improved diagnostics, new resistant potato cultivars, new resistant tomato cultivars, and new approaches to achieving host resistance. Efforts to meet some of these needs have been initiated. Of all of these, the need to improve diagnostics for specific traits of the pathogen is of particularly high priority. This is because, although use of microsatellite and allozyme markers to identify a particular lineage is currently effective to predict important phenotypic traits in the highly clonal population in the United States, that approach is unlikely to always be effective. For example, this approach will not be effective for a population into which new genotypes (with new phenotypes) are introduced. The most likely pathways for the introduction of new genotypes are via migration and via sexual recombination. Some migration is expected. However, perhaps the more important pathway will be via sexual recombination in the $P$. infestans population in the United States. It seems highly likely that eventually the population of $P$. infestans in the United States will become sexual. Thus, one goal of the AFRI project is to develop rapid specific diagnostic procedures for detecting certain traits. For example, if the gene responsible for mefenoxam resistance were known, one could develop a PCR-based assay that would be a direct diagnosis. Additionally, if the effectors recognized by $\mathrm{Ph} 2$ and $\mathrm{Ph} 3$ were known, one could assay for these effectors using molecular tools.

Fortunately, research on late blight of potato and tomato is being conducted all over the world, and technologies and approaches developed in one location can be rapidly adopted elsewhere. Exciting new developments in our understanding of the genome of the pathogen, of plant responses, and of the biology, ecology, and epidemiology of the pathogen have converged to stimulate integrated projects on late blight all over the world. It is important to emphasize to growers and policy makers that an integrated approach is needed and to remind them that previous reliance on a single "silver bullet" approach has always been transitory.

\section{Acknowledgments}

This work was sponsored by the institutions of each of the authors. Additionally, some of the work was sponsored by the Agriculture and Food Research Initiative Competitive Grants Program Grant 2011-68004-30154 from the USDA, and by the USDA NE-IPM Regional IPM program Special Grant NYC153560 .

\section{Literature Cited}

1. Adl, S. M., Simpson, A. G. B., Farmer, M. A., Andersen, R. A., Anderson, O. R., Barta, J. R., Bowser, S. S., Brugerolle, G. U. Y., Fensome, R. A., Fredericq, S., James, T. Y., Karpov, S., Kugrens, P., Krug, J., Lane, C. E. Lewis, L. A., Lodge, J., Lynn, D. H., Mann, D. G., McCourt, R. M., Mendoza, L., Moestrup, O., Mozley-Standridge, S. E., Nerad, T. A., Shearer, C. A., Smirnov, A. V., Spiegel, F. W., and Taylor, M. F. J. R. 2005. The New Higher Level Classification of Eukaryotes with Emphasis on the Taxonomy of Protists. J. Eukaryotic Microbiol. 52(5):399-451.

2. Andersson, B., Sandstrom, M., and Stromberg, A. 1998. Indications of soil borne inoculum of Phytophthora infestans. Potato Res. 41:305-310.

3. Andrade-Piedra, J., Hijmans, R. J., Forbes, G. A., Fry, W. E., and Nelson, R. J. 2005. Simulation of potato late blight in the Andes: I, Modification and parameterization of the LATEBLIGHT model. Phytopathology 95:11911199.

4. Andrade-Piedra, J., Hijmans, R. J., Juarez, H. S., Forbes, G. A., Shtienberg, D., and Fry, W. E. 2005. Simulation of potato late blight in the Andes: II. Validation of the LATEBLIGHT model. Phytopathology 95:1200-1208.

5. Andrade-Piedra, J. L., Forbes, G. A., Shtienberg, D., Grünwald, N. J., Chacón, M. G., Taipe, M. V., Hijmans, R. J., and Fry, W. E. 2005. Qualification of a plant disease simulation model: Performance of the LATEBLIGHT model across a broad range of environments. Phytopathology 95:1412-1422.

6. Andrivon, D. 1995. Biology, ecology, and epidemiology of the potato late blight pathogen Phytophthora infestans in soil. Phytopathology 85:10531056.

7. Barber, D. 2009. You say tomato, I say agricultural disaster. In: New York Times, New York.

8. Becktell, M. C., Daughtrey, M. L., and Fry, W. E. 2005. Epidemiology and management of petunia and tomato late blight in the greenhouse. Plant Dis. 89:1000-1008.

9. Becktell, M. C., Daughtrey, M. L., and Fry, W. E. 2005. Temperature and leaf wetness requirements for pathogen establishment, incubation period and sporulation of Phytophthora infestans on Petunia $\times$ hybrida. Plant Dis. 89:975-979.

10. Becktell, M. C., Smart, C. D., Haney, C. H., and Fry, W. E. 2006. Hostpathogen interactions between Phytophthora infestans and the solanaceous hosts Calibrachoa $\times$ hybridus, Petunia $\times$ hybrida and Nicotiana benthamiana. Plant Dis. 90:24-32.

11. Bourke, A. 1993. 'The Visitation of God'? The potato and the great Irish famine. Lilliput Press, Ltd., Arbour Hill,, Dublin, Ireland.

12. Boyd, A. E. W. 1980. Development of potato blight (Phytophthora infestans) after planting infected seed tubers. Ann. Appl. Biol. 95:301-309.

13. Bruhn, J. A., and Fry, W. E. 1981. Analysis of potato late blight epidemiology via simulation modeling. Phytopathology 71:612-616.

14. Crosier, W. 1934. Studies in the biology of Phytophthora infestans (Mont) de Bary. Cornell University Agricultural Experiment Station, Ithaca, NY (Memoir 155)

15. Danies, G., Small, I. M., Myers, K., Zuluaga, A. P., Childers, R., Becoscke, K., Stead, S., Teerantanonon, A., D’Attilio, D., and Fry, W. E. 2012. Phenotypic and Genotypic Characterization of Recent Clonal Lineages of Phytophthora infestans in the United States and Canada. Phytopathology 102:S4.28.

16. Doster, M. A., Sweigard, J. A., and Fry, W. E. 1989. The influence of host resistance and climate on the initial appearance of foliar late blight of potato from infected tubers. Am. Potato J. 66:227-233.

17. Drenth, A., Janssen, E. M., and Govers, F. 1995. Formation and survival of oospores of Phytophthora infestans under natural conditions. Plant Pathol. 44:86-94.

18. Erwin, D. C., and Ribeiro, O. K. 1996. Phytophthora Diseases Worldwide. American Phytopathological Society, St. Paul, MN.

19. Fay, J. C., and Fry, W. E. 1997. Effects of hot and cold temperatures on the survival of oospores produced by United States strains of Phytophthora infestans. Am. Potato J. 74(5):315-323.

20. Fernandez-Pavia, S. P., Grunwald, N. J., Diaz-Valasis, M., CadenaHinojosa, M. A., and Fry, W. E. 2004. Soil-borne oospores of Phytophthora infestans in central Mexico survive winter fall and infect potato plants in the field. Plant Dis. 88:29-33.

21. Fry, W. 2008. Phytophthora infestans: The plant (and R gene) destroyer Mol. Plant Pathol. 9(3):385-402.

22. Fry, W. E., Apple, A. E., and Bruhn, J. A. 1983. Evaluation of potato late blight forecasts modified to incorporate host resistance and fungicide weathering. Phytopathology 73:1054-1059.

23. Fry, W. E., and Goodwin, S. B. 1997. Re-emergence of potato and tomato late blight in the United States. Plant Dis. 81(12):1349-1357.

24. Fry, W. E., Goodwin, S. B., Matuszak, J. M., Spielman, L. J., Milgroom, M. G., and Drenth, A. 1992. Population genetics and intercontinental migrations of Phytophthora infestans. Annu. Rev. Phytopathol. 30:107-129.

25. Fry, W. E., Grunwald, N. J., Cooke, D. E. L., McLeod, A., Forbes, G. A., and Cao, K. 2009. Oomycete genetics and genomics: Diversity, interactions and research tools: 139-164. Wiley-Blackwell, Hoboken, NJ.

26. Goodwin, S. B., Cohen, B. A., and Fry, W. E. 1994. Panglobal distribution of a single clonal lineage of the Irish potato famine fungus. Proc. National 
Acad. Sci. USA 91:11591-11595.

27. Goodwin, S. B., Drenth, A., and Fry, W. E. 1992. Cloning and genetic analyses of two highly polymorphic, moderately repetitive nuclear DNAs from Phytophthora infestans. Curr. Genet. 22:107-115.

28. Goodwin, S. B., Schneider, R. E., and Fry, W. E. 1995. Use of celluloseacetate electrophoresis provides rapid identification of allozyme genotypes of Phytophthora infestans. Plant Dis. 79:1181-1185.

29. Goodwin, S. B., Sujkowski, L. S., and Fry, W. E. 1996. Widespread distribution and probable origin of resistance to metalaxyl in clonal genotypes of Phytophthora infestans in the United States and western Canada. Phytopathology 86:793-800.

30. Grünwald, N. J., and Flier, W. G. 2005. The biology of Phytophthora infestans at its center of origin. Annu. Rev. Phytopathol. 43(1):171-190.

31. Hirst, J. M., and Stedman, O. J. 1960. The epidemiology of Phytophthora infestans. II. The source of inoculum. Ann. Appl. Biol. 48:489-517.

32. Hohl, H. R., and Iselin, K. 1984. Strains of Phytophthora infestans with A2 mating type behaviour. Trans. Br. Mycol. Soc. 83:529-530.

33. Hu, C.-H., Perez, F., Donohoo, R., McLeod, A., Myers, K., Ivors, K., Secor, G., Roberts, P., Deahl, K., Fry, W. E., and Ristaino, J. B. 2012. Recent genotypes of Phytophthora infestans in eastern USA reveal clonal populations and reappearance of mefenoxam sensitivity. Plant Dis. 96:1323-1330.

34. Kato, M., Mizubuti, E. S. G., Goodwin, S. B., and Fry, W. E. 1997. Sensitivity to protectant fungicides and pathogenic fitness of clonal lineages of Phytophthora infestans in the United States. Phytopathology 87:973-978.

35. Krause, R. A., and Massie, L. B. 1975. Blitecast: A computerized forecast of potato late blight. Plant Dis. Rep. 59:95-98.

36. Lacey, J. 1965. The infectivity of soils containing Phytophthora infestans. Ann. Appl. Biol. 56:363-380.

37. Lees, A. K., Wattier, R., Shaw, D. S., Sullivan, L., Williams, N. A., and Cooke, D. E. L. 2006. Novel microsatellite markers for the analysis of Phytophthora infestans populations. Plant Pathol. 55(3):311-319.

38. Mayton, H., Smart, C. D., Moravec, B. C., Mizubuti, E. S. G., Muldoon, A. E., and Fry, W. E. 2000. Oospore survival and pathogenicity of single oospore recombinant progeny from a cross involving the US-8 and US-17 lineages of Phytophthora infestans. Plant Dis. 84:1190-1196.

39. Minogue, K. P., and Fry, W. E. 1981. Effect of temperature, relative humidity, and rehydration rate on germination of dried sporangia of Phytophthora infestans. Phytopathology 71:1181-1184.

40. Mizubuti, E. S. G., Aylor, D. E., and Fry, W. E. 2000. Survival of Phytophthora infestans sporangia exposed to solar radiation. Phytopathology 90:78-84.

41. Moskin, J. 2009. Outbreak of fungus threatens tomato crop. In: New York Times, New York.

42. Myers, K. L., Childers, R., Camuzeaux, D., Danies, G., Small, I. M., and Fry, W. E. 2012. Mefenoxam sensitivity of recent strains of Phytophthora infestans in the United States. Phytopathology 102:S4.84

43. Niederhauser, J. S. 1991. Phytophthora: 25-45. Cambridge University Press, Cambridge.

44. Small, I. M., Myers, K., Danies, G., Guha Roy, S., Bekoscke, K., and Fry, W. E. 2012. Characterization of recent clonal lineages of Phytophthora infestans in the United States using microsatellite markers. Phytopathology 102:S4.110

45. Smart, C. D., Myers, K. L., Restrepo, S., Martin, G. B., and Fry, W. E. 2003. Partial resistance of tomato to Phytophthora infestans is not dependent upon ethylene, jasmonic acid or salicyclic acid signalling pathways. Mol. Plant-Microbe Interact. 16:141-148.

46. Smoot, J. J., Gough, F. J., Lamey, H. A., Eichenmuller, J. J., and Gallegly, M. E. 1958. Production and germination of oospores of Phytophthora infestans. Phytopathology 48:165-171.

47. Stevens, N. E. 1933. The dark ages in plant pathology in America: 18301870. J. Washington Acad. Sci. 23:435-446.

48. Sujkowski, L. S., Goodwin, S. B., Dyer, A. T., and Fry, W. E. 1994. Increased genotypic diversity via migration and possible occurrence of sexual reproduction of Phytophthora infestans in Poland. Phytopathology 84:201-207.

49. Woodham-Smith, C. 1962. The Great Hunger. Harper \& Row, New York.

On 22 March 2013, this article was changed. A credit was added to the caption for the dendrogram in Figure 12. 